УДК 792 / 796.4

Дмитро Володимирович Орел,

Київська муніципальна академія естрадного та циркового мистецтв,

Київ, Україна, e-mail: artplatforma88@gmail.com, ORCID ID 0000-0002-2413-1676

\title{
ДО ПРОБЛЕМИ ВИКЛАДАННЯ НАВЧАЛЬНИХ ДИСЦИПЛІН СПЕЦІАЛІЗАЦЇ̈ «АКРОБАТИКА» У ЗВО МИСТЕЦЬКОГО СПРЯМУВАННЯ (НА ПРИКЛАДІ КМАЕЦМ)
}

\begin{abstract}
Анотація. У статті проаналізовано специфіку викладання у вищому навчальному закладі мистецького спрямування дисциплін спеціалізації «акробатика» як циркового жанру. Мета дослідження полягає в системному аналізі методів підготовки майбутнього професійного артиста циркових жанрів - акробата, викладача. Викладено стислий аналіз основних віх історії вітчизняної акробатичної школи через призму його видатних персоналій. Розглядається творчість представників 50х-90-х pp. ХХ ст., їх значний внесок у вітчизняну школу циркової акробатики, акцентуються унікальні трюкові вправи. Представлено аналіз роботи попередників із дотичною проблематикою у різних жанрах циркового мистецтва, їх специфіка форм, технік, жанрів, сценічних та технічних особливостей реквізиту. Проаналізовано особливості термінологічного апарату, окремі важливі вправи, благоустрій, специфічна уніформа, дисциплінарні особливості, специфіку технічного оснащення циркового реквізиту. Зроблено акцент на тому, що сучасна циркова професійна освіта збагачується результатами взаємодії з новими технологіями спорту, пластики, танцю, з новітніми технологіями. Чітке виконання вправ і рухів, знання професійної термінології, понятійного апарату, вміння
\end{abstract}


логічно будувати та системно викладати навчальні дисципліни спеціалізації «Акробатика» надають можливість сучасній молоді бути конкурентоздатною на всесвітньому цирковому ринку праці та гідно презентувати себе на фестивалях та конкурсах.

Ключові слова: циркове мистецтво, цирковий жанр, циркова акробатика, фестиваль, спорт

Вступ. У статті визначено аналіз специфічних рис акробатики як циркового жанру, іï видатних історичних персоналій, досягнення яких являють собою вітчизняний культурний спадок, а також окреслено специфічні риси методики викладання дисциплін жанру «Акробатика» у ЗВО.

Постановка проблеми. Акробатика посідає у масиві сценічних мистецтва, зокрема в цирковому мистецтві та хореографії, домінуюче місце порівняно 3 іншими жанрами, завдяки різноманітності видів, розмаїттю типів вправ і форм виконання. Володіння прийомами акробатики необхідне кожному професіональному артисту цирку: еквілібристу, гімнасту, жонглеру, клоуну, міму. Важливо це і для сучасних хореографів - артистів балету та танцювальних ансамблів і колективів.

Аналіз останніх досліджень і публікацій. Вітчизняні напрацювання в галузі циркознавства є поки доволі скудними, бо галузь перебуває в стадії становлення. Основні вектори представлені теоретичними штудіями таких дослідників, як Світлана Добровольська [14], Володимир Кашеварів [1], Юрій Кашуба [13], Анатолій Стеценко [14], Марина Малихіна [4], Олена Пожарська [5], Михайло Рибаков [9], Юлія Романенкова $[6 ; 7 ; 8]$, Денис Шариков [10], Світлана Шумакова $[11 ; 12]$. У роботі Михайла Рибакова проведений скрупульозний аналіз історичного процесу становлення та розвитку Київського цирку. Проаналізовані певні періоди його функціонування, висвітлено існуючі в рамках циркового простору Києва циркові жанри акробатика, повітряна гімнастика, еквілібристика, клоунада, 
пантоміма, ілюзія та маніпуляція, жонглювання, оригінальні циркові жанри, наведено дані про унікальні трюки і технічні особливості роботи видатних артистів цирку XX ст.

Частина циркознавчих розробок має суто теоретичний характер $[4 ; 5 ; 6-8 ; 10 ; 11 ; 12]$, і лише деякі присвячені практичному боку справи та мають характер методичних рекомендацій, висвітлюючи прикладний аспект $[1 ; 10 ; 13 ; 14]$. Наприклад, Анатолій Стеценко та Світлана Добровольська у праці «Специфічні особливості в сценічному методі жанру «Циркова гімнастика»: формально-технічні характеристики, а також аналіз роботи повітряної гімнастики на трапеції» розглянули особливості сценічного методу жанру «Циркова гімнастика» в контексті циркової профільної освіти, подали аналіз окремих понять галузі гімнастики, що сприятиме розумінню їх специфіки, описали елементи роботи в повітряній гімнастиці на трапеції [7, с. 96].

Мета дослідження полягає в системному аналізі підготовки майбутнього професійного артиста циркових жанрів - акробата, викладача, в умовах сучасного українського ЗВО.

Виклад основного матеріалу. В українському цирку досить багато персоналій, знання творчих біографій яких сприятиме розумінню загальних процесів, пов'язаних із становленням української циркової школи. Торкнемося найвидатніших циркових артистів, представників акробатики київської школи, вагомих майстрів спортивних змагань та манежу, щоб створити уявлення про іiі характер та динаміку розвитку.

Серед старожилів київського манежу можна виділити , наприклад, Володимира Кашеварова. Акробат-стрибун, повітряний гімнаст 1960-1990-х pp. ХХ ст., він здобув популярність у цирковому світі передумім своїм знаковим номером «Акробати на верблюдах “Кадиргулям"» під керівництвом Владислава Янушевского. По ходу виконання номеру артист запам'ятався публіці найяскравішими трюками: 
«Сальто вперед через п’ять верблюдів», «Рондад заднє сальто за бар'єр». Не менш яскравим був і номер акробатів-стрибунів в акробатичному ансамблі «Черемош» під керівництвом заслуженого артиста УРСР Віктора Максимова. Його найяскравіші трюки - «Подвійне сальто назад на килимі», «Подвійне сальто 3 гвинтом» (з обертом на $360^{\circ}$ ), «Арабські сальто по колу на манежі» - стали візитівкою акробата. Був у творчому здобутку артиста і дуетний номер - повітряна рамка «Повітряне кохання» 3 партнеркою та дружиною, заслуженою артисткою України Світланою Кашеваровою. Найхарактерніші трюки цього номеру - «Подвійне сальто вперед в руки партнеру», «Вольтижна робота та кабріоль із партнеркою» завжди впадали в око глядачам. По завершенні кар'єри артист посів місце інспектора манежу Національного цирку України [1, c. 18].

Серед еквілібристів української циркової школи помітну роль відігравав Анатолій Стеценко - еквілібрист на першах, заслужений артист України, що працював в Україні та країнах світу впродовж 1970-1990 рр. Видатним номером, побудованим на принципах синтезу циркових жанрів, був акробатичний хендвольтиж $з$ еквілібром із першами, номер «Летючі перши», при випуску якого було змінено загальноприйняте візуальне бачення статичного руху перша на його динамічний рух у просторі. Серед найпоказовіших трюків номеру - «Кидок перша з верхнім від одного нижнього до іншого», «Переліт верхнього 3 перша до середнього, який стоїть на перші», «Кидок перша з чотирьох рук партнеру, який стоїть на ходулях». У подальшому цей дивовижний номер був відновлений у 2014 р. та продовжує репрезентуватись на арені Національного цирку України під керівництвом Віктора Ярова за участі випускниці Київської муніципальної академії естрадного та циркового мистецтв Тетяни Заремби [7, р. 97].

Українська циркова школа неможлива і без Валерія Піроговського - акробата на підкидних дошках, що працював у 
1970-1980 pр. при «Союздержцирку» під керівництвом народного артиста України Володимира Шевченка. Він прославився видатними трюками: «Колона 3 чотирьох чоловік, де п'ятий робив захід у плечі (вилітав)», «Два бланжи, чотири задніх сальто мортале в плечі», ін. Його партнер, Сергій Ханов, у номері відзначився унікальним трюком «Потрійне сальто на одній ходулі» [3, с. 17].

Заняття акробатикою забезпечують відмінний розвиток усіх м’язів, зміцнюють фізичну силу, спритність, витривалість, покращують моторні здібності, пластичну виразність i координацію рухів, благотворно впливають на весь організм людини в цілому, додають постаті гарну поставу, а також сприяють вихованню вольових якостей майбутнього артиста. Заняття з акробатики включають у себе певні комплекси рухів, які здійснюють навантаження на всі групи м'язів. Для цього застосовуються спеціальні підготовчі вправи, які сприяють розвитку й укріпленню м'язів та суглобів і допомагають засвоєнню програмних акробатичних елементів і вправ.

В умовах 3ВО, де готують майбутніх циркових артистів, акробатів, опанування акробатичних вправ починається з усного пояснення викладача, мета якого - чітке усвідомлення студентом техніки та послідовності виконання акробатичних елементів і вправ. Практичне засвоєння акробатичних елементів i вправ, особливо на початковому етапі, обов'язково здійснюється із застосуванням допомоги та професійного страхування студентів викладачем (підтримки, утримання, лонжа). Переходити до вивчення нових, складніших акробатичних вправ необхідно тільки після практичного засвоєння попередніх [3, с. 52].

Провідним 3ВО, де сьогодні в Україні готують акробатів, є Київська муніципальна академія естрадного та циркового мистецтв. Як i будь-який навчальний процес, навчання акробатичним вправам будується на дидактичних 
принципах, але має свої специфічні особливості, властиві вітчизняній акробатичній школі.

Для успішного виконання акробатичних вправ студентами бакалаврату освітньо-професійної програми «Циркові жанри», спеціальності 026 «Сценічне мистецтво» потрібно дотримуватись деяких обов'язкових правил і будувати заняття бажано за таким принципом: 1) підготовча частина розігрівання м'язів; 2) основна частина - засвоєння виключно технічних вправ, де напруга $\epsilon$ максимальною; 3) заключна частина - виконання вправ на силу та розтягування м'язів i розслаблення. Співвідношення цих частин та повторення i закріплення вивченого матеріалу регламентується викладачем, виходячи 3 необхідності. На початковому етапі вивчення акробатичних вправ допомога викладача, вміле страхування виховують у студентів впевненість у своїх силах та сприяють швидкому переборюванню страху і труднощів [6, с. 102].

Заняття зі спеціалізації «Акробатика» повинні бути різносторонніми, навантаження мають лягати на різнорідні групи м'язів. Наприклад, статичні вправи - на розвиток гнучкості і розтягування, кульбіти, темпові вправи. Основні вміння, якими повинен володіти студент бакалаврату спеціалізації «Акробатика», та поняття, які він повинен знати, викладені в освітньо-професійній програмі «Циркові жанри». Серед основних для засвоєння термінів наступні: акробатика як жанр (та іiі різновиди), акробатичний вольтиж, акробатична доріжка, бланш, вальсет, вхід та схід із плечей, гвинт, зіскок, колесо, kopfsprung (копфшпрунг), копфштейн, culbute (кульбіт), courbette (курбет), лягскач, лонжа, мат, міст, пасеровка, переворот, перекидка, прапорець, розігрів, рондат, «із решітки в решітку», salto (сальто), сальто-мортале, стійка «кисті в кисті», страховка, стрекасат, темп, угрупування, хват, flic-flac (флікфляк), vordersprung (фордершпунг), «із фуса», шпагат [5]. 
Передбачено, що в результаті опанування комплексом практичних навичок і теоретичних знань студенти бакалаврату спеціалізації «Акробатика» повинні:

- володіти ефективними прийомами збереження рівноваги тіла;

- правильно провести розігрів, включаючи прості та ефективні вправи;

- коректно застосовувати страхувальні засоби, необхідні як при опануванні, так і при виконанні акробатичних елементів і вправ;

- правильно виконувати як прості, так і складні акробатичні елементи і вправи;

- правильно аналізувати власну техніку виконання акробатичних елементів і вправ, уміти вчасно знаходити та виправляти помилки технічного характеру;

- на основі засвоєного програмного матеріалу 3 акробатики вміти правильно складати та виконувати прості і складні акробатичні комбінації.

Заняття зі спеціалізації «Акробатика» забезпечують у свою чергу всебічний фізичний розвиток на основі $\mathrm{i}$ в органічному зв'язку з вимогами і нормами підготовки артистів, дають змогу в цілому вдосконалювати майстерність виконавців.

Висновки. Таким чином, чітке виконання вправ і рухів, знання професійної термінології та знання понятійного апарату, а також вміння логічно будувати та системно проводити заняття 3 акробатики надає можливості сучасним молодим акробатам бути не тільки конкурентоспроможними як артисти, а також особистісно сформуватися як фахівці-викладачі.

\section{Література}

1. Кашеваров В., Орел Д. Сценічно-технічна підготовка в циркових жанрах: техніка безпеки, манеж, реквізит. Київ: КМАЕЦМ, 2018. 75 с.

2. Кисленко А. Акробатика. Методические рекомендации по обучению акробатическим упражнениям для учителей 
физической культуры. Климовск: Методический кабинет отдела образования администрации Климовского района, 2006. 17 с.

3. Коркин В. Акробатика. Москва: Физкультура и спорт, 2012. 127 c.

4. Малихіна, М. Професійна циркова освіта в Україні. Культура і сучасність. 2012. Вип. 1. С. 174-179.

5. Пожарська, О. Зміст та функції циркового видовища. Молодий вчений, 2017, вип. 9(49), с.181-186.

6. Романенкова Ю. Современное цирковое искусство как поле для борьбы со стереотипами. Арт-платформа, 2020. Вып. 1. C.69-93.

7. Романенкова Ю. Сучасна українська циркова школа як інструмент презентування країни у світовому культурному просторі. Молодий вчений. 2020. 3(79), с. 69-73.

8. Романенкова Ю., Игнатов А., Гандзюк В. Эксперименты молодых артистов в жанре парного ручного эквилибра в контексте развития украинского проекта «Raw цирк». Science, research, development. London, 2018. C. 29-34.

9. Рыбаков М. Киевский цирк: люди, события, судьбы. Киев: Атика, 2006300 с.

10. Шариков Д. Балетна та циркова неокласика: інтеграційні процеси, синтез та трансформація. Арт-платформа, 2020. Вып. 1. C.109-125.

11. Шумакова С. Генезис и эволюция харьковской школы циркового искусства: автореф. дис. канд.иск. Харьков, 2015. $12 \mathrm{c}$.

12. Шумакова С. Генезис Харківської школи циркового мистецтва в контексті становлення цирку Харкова. Мистецтвознавчі записки. 2013. Вип. 24. С. 203-210.

13. Kashuba Yu. Specific features of circus acrobatics: power acrobatics, analysis of the scenic method in the Kiev Municipal Academy of Variety and Circus Art. Innovative solutions in modern science, 2018, 6 (25), 100-105. 
14. Stetsenko A., Dobrovolskaya S. Specific features of the scenic method in the genre "Circus Gymnastics": formal technical characteristics, as well as analysis of tricks on "Shvung Trape" (trapezium). Innovative solutions in modern science, 2018, 6 (25), p. 95-99.

Орел Дмитрий Владимирович,

Киевская муниципальная академия эстрадного и циркового искусств, Киев, Украина, e-mail: artplatforma88@gmail.com, ORCID ID 0000-0002-2413-1676

\title{
К ПРОБЛЕМЕ ПРЕПОДАВАНИЯ УЧЕБНЫХ ДИСЦИПЛИН СПЕЦИАЛИЗАЦИИ «АКРОБАТИКА» В ВУЗЕ ХУДОЖЕСТВЕННОГО НАПРАВЛЕНИЯ (НА ПРИМЕРЕ КМАЕЦМ)
}

\begin{abstract}
Аннотация. В статье проанализирована специфика преподавания в высшем учебном заведении художественного направления дисциплин специализации «Акробатика» как циркового жанра. Цель исследования заключается в системном анализе методов подготовки будущего профессионального артиста цирковых жанров - акробата, преподавателя. Изложен краткий анализ истории отечественной акробатической школы через призму его выдающихся персоналий. Рассматривается творчество представителей 60-х-90-х гг. ХХ в., их значительный вклад в отечественную школу цирковой акробатики, акцентируются уникальные трюковые упражнения. Представлен анализ работы предшественников с касательной проблематикой в разных жанрах циркового искусства, их специфики, форм, техник, жанров, сценических и технических особенностей реквизита. Проанализированы особенности терминологического
\end{abstract}


аппарата, отдельные важные упражнения, благоустройство, специфическая униформа, дисциплинарные особенности, специфику технического оснащения циркового реквизита. Сделан акцент на том, что современное цирковое профессиональное образование обогащается результатам взаимодействия с новыми технологиями спорта, пластики, танца. Четкое выполнение упражнений и движений, знание профессиональной терминологии, понятийного аппарата, умение логически строить и системно преподавать дисциплины специализации «Акробатика» предоставляют возможность современной молодежи быть конкурентоспособной на всемирном цирковом рынке труда и достойно представить себя на фестивалях и конкурсах.

Ключевые слова: цирковое искусство, цирковой жанр, цирковая акробатика, фестиваль, спорт

\author{
Dmytro V. Orel, \\ Kyiv Municipal Academy of Circus and Variety Arts, \\ Kyiv, Ukraine, \\ e-mail: artplatforma88@gmail.com, \\ ORCID ID 0000-0002-2413-1676
}

\title{
TO THE PROBLEM OF TEACHING THE EDUCATIONAL DISCIPLINES OF THE SPECIALIZATION "ACROBATICS" AT HIGH ART INSTITUTIONS (ON KMACVA)
}

\begin{abstract}
The article analyzes the specifics of teaching of the disciplines of specialization "Acrobatics" as a circus genre in a art high educational institutions. The aim of the research is to systematically analyze the methods of training a future professional circus artist - acrobat, teacher. A brief analysis of the history of the Ukrainian acrobatic school through the prism of its outstanding personalities is presented. A brief analysis of the history of the
\end{abstract}


domestic acrobatic school through the prism of its outstanding personalities is presented. The creativity of representatives is considered $60-90 \mathrm{~s}$ of the $\mathrm{XX}^{\text {th }}$ century, their significant contribution to the domestic school of circus acrobatics, unique stunt exercises are emphasized. An analysis of the work of predecessors with tangential problems in different genres of circus art, their specificity, forms, techniques, genres, stage and technical features of the props is presented. The features of the terminological apparatus, some important exercises, landscaping, specific uniforms, disciplinary features, the specifics of the technical equipment of circus props are analyzed. The emphasis is made on the fact that modern circus professional education is enriched by the results of interaction with new technologies of sports, plastics, dance, and the latest technologies. Accurate performance of exercises and movements, knowledge of professional terminology, conceptual apparatus, the ability to logically construct and systematically present the disciplines of the specialization "Acrobatics" provide an opportunity for modern youth to be competitive in the world circus labor market and present themselves worthily at festivals and competitions.

Key words: circus art, circus genre, circus acrobatics, festival, sport

\section{References}

1. Kashevarov, V., Orel, D. (2018). Scenichno-tekhnichna pidgotovka v cirkovih zhanrah: tekhnika bezpeki, manezh, rekvizit [Stage and technical training in circus genres: safety equipment, playpen, props]. Kyiv: KMAVCA [in Ukrainian].

2. Kislenko, A. (2006). Akrobatika. Metodicheskie rekomendacii po obucheniyu akrobaticheskim uprazhneniyam dlya uchitelej fizicheskoj kul'tury. Klimovsk: Methodical cabinet of the Department of Education of the Administration of Klimovsky District [in Russian].

3. Korkin, V. (2012). Akrobatika. Moscow: Physical Culture and Sport [in Russian]. 
4. Malykhina, M. (2012). Profesiyna tsyrkova osvita v Ukrayini [Professional circus education in Ukraine]. Kul'tura i suchasnist, 1, 174-179 [in Ukrainian].

5. Pozhars'ka, O. (2017). Zmist ta funktsiyi tsyrkovoho vydovyshcha [Content and functions of the circus spectacle]. Molodyy vchenyy 9(49), 181-186 [in Ukrainian].

6. Romanenkova, Yu. (2020). Sovremennoye tsirkovoye iskusstvo kak pole dlya bor'by so stereotipami [Contemporary circus art as a field for combating stereotypes]. Art-platforma, 1, 69-93 [in Russian].

7. Romanenkova, Yu. (2020). Suchasna ukrayins'ka tsyrkova shkola yak instrument prezentuvannya krayiny u svitovomu kul'turnomu prostori [Modern Ukrainian circus school as a tool for presenting the country in the world cultural space]. Molodyy vchenyy, 3(79), 69-73 [in Ukrainian].

8. Romanenkova, Yu., Ignatov, A., Gandzyuk, V. (2018). Eksperimenty molodykh artistov $\mathrm{v}$ zhanre parnogo ruchnogo ekvilibra v kontekste razvitiya ukrainskogo proyekta «Raw tsirk» [Experiments of young artists in the genre of pair manual equilibrium in the context of the development of the Ukrainian project "Raw circus".]. Science, research, development. London, 29-34 [in Russian].

9. Rybakov, M. (2006). Kievskiy cirk: lyudi, sobytiya, sud'by [Kiev Circus: people, events, fates.] . Kyiv: Atica [in Ukrainian].

10. Kashuba, Yu. (2018). Specific features of circus acrobatics: power acrobatics, analysis of the scenic method in the Kiev Municipal Academy of Variety and Circus Art. Dubai, TK Meganom [in English].

15. Stetsenko, A., Dobrovolskaya, S. (2018). Specific features of the scenic method in the genre "Circus Gymnastics": formal technical characteristics, as well as analysis of tricks on "Shvung Trape" (trapezium). Innovative solutions in modern science, 6 (25), 95-99 [in English]. 